\section{REFERENCES}

1. Simor A, Ofner-Agostini M, Paton S, Canadian Hospital Epidemiology Committee, Bureau of Infectious Diseases, Laboratory Centre for Disease Control. The Canadian Nosocomial Infection Surveillance Program: results of the first two years of surveillance for methicillinresistant Staphylococcus aureus in Canadian hospitals. Can Commun Dis Rep 1997;23:41-45.

2. McGeer A, Low D, Conly J, Campbell I, Devlin R, Simor A, et al. Methicillin-resistant Staphylococcus aureus in Ontario. Can Commun Dis Rep 1997;23:45-46.

3. Boyce JM. Should we vigorously try to contain and control methicillinresistant Staphylococcus aureus? Infect Control Hosp Epidemiol 1991;12:46-54.

4. Boyce JM, Jackson MM, Pugliese G, Batt MD, Fleming D, Garner JS, et al. Methicillin-resistant Staphylococcus aureus (MRSA): a briefing for acute care hospitals and nursing facilities. Infect Control Hosp Epidemiol 1994;15:105-115.

5. Pearman JW, Christiansen KJ, Annear DI, Goodwin CS, Metcalf C, Donovan FP, et al. Control of methicillin-resistant Staphylococcus aureus (MRSA) in an Australian metropolitan teaching hospital complex. Med J Aust 1985;142:103-108.

6. Jernigan JA, Clemence MA, Stott GA, Titus MG, Alexander CH, Palumbo CM, et al. Control of methicillin-resistant Staphylococcus aureus at a university hospital: one decade later. Infect Control Hosp Epidemiol 1995;16:686-696.

7. National Committee for Clinical Laboratory Standards. Methods for Dilution Antimicrobial Susceptibility Tests for Bacteria that Grow Aerobically. 4th ed. Approved standard M7-A4. Wayne, Pa: NCCIS; 1997.

8. Troillet N, Carmeli Y, Samore MH, Dakos J, Eichelberger K, DeGirolami PC, et al. Carriage of methicillin-resistant Staphylococcus aureus at hospital admission. Infect Control Hosp Epidemiol 1998;19:181-185.

9. Preheim LC, Rimland D, Bittner MJ. Methicillin-resistant Staphylococcus aureus in Veterans Administration medical centers. Infect Control
1987;8:191-194.

10. Haley RW, Hightower AW, Khabbaz RF, Thornsberry C, Martone WJ, Allen JR, et al. The emergence of methicillin-resistant Staphylococcus aureus infections in United States hospitals. Possible role of the house staff-patient transfer circuit. Ann Intern Med 1982;97:297-308.

11. Mulligan ME, Murray-Leisure KA, Ribner BS, Standiford HC, John JF, Korvick JA, et al. Methicillin-resistant Staphylococcus aureus: a consensus review of the microbiology, pathogenesis, and epidemiology with implications for prevention and management. Am J Med 1993:94:313-328.

12. Sanford MD, Widmer AF, Bale MJ, Jones RN, Wenzel RP. Efficient detection and long-term persistence of the carriage of methicillin-resistant Staphylococcus aureus. Clin Infect Dis 1994:19:1123-1128.

13. Law MR, Gill ON, Turner A. Methicillin-resistant Staphylococcus aureus: associated morbidity and effectiveness of control measures. Epidemiol Infect 1988;101:301-309.

14. Walsh TJ, Vlahov D, Hansen SL, Sonnenberg E, Khabbaz R, Gadacz T, et al. Prospective microbiologic surveillance in control of nosocomial methicillin-resistant Staphylococcus aureus. Infect Control 1987;8:7-14.

15. Van Enk RA, Thompson KD. Use of a primary isolation medium for recovery of methicillin-resistant Staphylococcus aureus. J Clin Microbiol 1992;30:504-505.

16. Dacre J, Emmerson AM, Jenner EA Gentamicin-methicillin-resistant Staphylococcus aureus: epidemiology and containment of an outbreak. $J$ Hosp Infect 1986;7:130-136.

17. Cox RA, Conquest C, Mallaghan C, Marples RR. A major outbreak of methicillin-resistant Staphylococcus aureus caused by a new phage-type (EMRSA-16). J Hosp Infect 1995;29:87-106.

18. Rao N, Jacobs S, Joyce L. Cost-effective eradication of an outbreak of methicillin-resistant Staphylococcus aureus in a community teaching hospital. Infect Control Hosp Epidemiol 1988;9:255-260.

19. Wakefield DS, Helms CM, Massanari RM, Mori M, Pfaller M. Cost of nosocomial infection: relative contributions of laboratory, antibiotic, and per diem costs in serious Staphylococcus aureus infections. Am I Infect Control 1988;16:185-192.

\title{
Serogroup B Meningococcal Disease in Oregon
}

\section{Gina Pugliese, RN, MS Martin S. Favero, PhD}

The incidence of serogroup $B$ meningococcal disease, particularly ET-5 clonal strains, is continuing at high levels in Oregon.

To evaluate the impact of the ET-5 strain on epidemiology of meningococcal disease in Oregon, an epidemiological analysis of surveillance data in Oregon from 1987 to 1996 and multilocus enzyme electrophoresis typing of serogroup B isolates from June 1993 through April 1995 and from April through June 1996 was done. A total of 836 persons with invasive meningococcal disease were identified.
Serogroup B disease incidence rates more than doubled in Oregon from the pre-epidemic period of 1987 to 1992 (1.0 case/100,000 population) to the recent epidemic period, 1995 and 1996 (2.2 cases $/ 100,000)$. The age-specific incidence rate of serogroup $B$ disease among those 15 through 19 years old increased 13fold between the pre-epidemic (0.5 case $(100,000)$ and the epidemic period $(6.4$ cases $/ 100,000)$. However, the proportion of cases with meningococcemia and the case-fatality rate did not change. Of 99 Neisseria meningitidis isolates obtained from 1993 to 1995,88 ( $89 \%$ ) belonged to the ET-5 complex. Of these, $69(78 \%)$ were a single clone, designated 301 . Of 20 serogroup B isolates from 1996, 18 (90\%) belonged to the ET-5 complex; 17 (94\%) were the 301 clone.

The researchers noted that the annual incidence of meningococcal disease in Oregon currently is four times the national rate. The data indicate that serogroup $B$ meningococcal disease incidence continues at high levels in Oregon with increasing predominance of the ET-5 clonal strains.

FROM: Diermayer M, Hedberg K, Hoesly F, Fischer M, Perkins B, Reeves M, et al. Epidemic serogroup $\mathrm{B}$ meningococcal disease in Oregon. JAMA 1999;281:1493-1497. 